\title{
ARTICLE
}

\section{Additions to the vascular flora of Mongolia - IV}

\author{
Urgamal M. ${ }^{1 *}$, Gundegmaa $V_{.}^{2}$, Baasanmunkh $S .^{3}$ \\ Oyuntsetseg B. ${ }^{4}$, Darikhand $D .{ }^{5}$ and Munkh-Erdene T. \\ ${ }^{I}$ Laboratory of Flora and Plant Systematic, Institute of General and Experimental Biology, \\ Mongolian Academy of Sciences, Ulaanbaatar, Mongolia \\ ${ }^{2}$ Department of Biology, School of Mathematics and Natural Sciences, \\ Mongolian National University of Education, Ulaanbaatar, Mongolia \\ ${ }^{3}$ Department of Biology \& Chemistry, Changwon National University, \\ Changwon, South Korea \\ ${ }^{4}$ Department of Biology, School of Arts and Sciences, \\ National University of Mongolia, Ulaanbaatar, Mongolia \\ ${ }^{5}$ Khovd University, Khovd, Mongolia
}

ARTICLE INFO: Received: 24 Apr, 2019; Accepted: 19 Jul, 2019

\begin{abstract}
The article presents updates on the new species recorded in the "Conspectus of the Vascular Plants of Mongolia" (Urgamal et al. 2014), and three articles published "Additions to the Vascular Flora of Mongolia - I, II, III (2013, 2014, 2016)" listed as new for the Mongolian floristic novelties and reported as well. The aim of this article is to officially report new records for vascular plants from Mongolia, and this includes the data in total, 28 species (with 2 infraspecies) from 19 genera and 12 families. In addition, Cerastium alpinum, Dianthus repens, Draba alpina, Eritrichium tianschanicum, Gastrolychnis violascens, Iris oxypetala, Papaver chakassicum, Papaver lapponicum, Potentilla turczaninowiana, Stellaria depressa (10 species) were newly recorded in the list of vascular flora of Mongolia. The newly added species come under the following families and genera: Caryophyllaceae (5 species), Ranunculaceae (4 species), and Rosaceae (4 species) families and Potentilla (4 species), Geranium (3 species), and Iris (3 species) genera. The most recent additions to the following phyto-geographical regions of Mongolia are: Mongolian Altai ( 9 species), Khovd (7 species), and Khangai (6 species) regions.

At present, 3191 taxa (including 134 subspecies and 34 varieties) of vascular plants, representing over 684 genera from 108 families, 39 orders, 12 classes, includes 5 divisions, and 3 superclades (Ferns, Gymnospermae and Angiospermae) are registered in Mongolia. Since the last conspectus (Urgamal et al. 2014) was published, lgenera, 64 species and subspecies have been newly added to the flora of Mongolia. The newly recorded 5 species are "endemic "and 9 species are "sub-endemic" to Mongolia. Therefore, currently a total of 125 species (3.91\%) are "endemic", and 532 species (16.65\%) are "sub-endemic" to the vascular flora of Mongolia, respectively.
\end{abstract}

Keywords: New records; endemic; sub-endemic; phyto-geographical region; vascular flora; Mongolia; 


\section{INTRODUCTION}

Mongolia's plant kingdom is rich and very diverse. Flora and vegetation research in Mongolia began in the $19^{\text {th }}$ century by researchers who were engaged in the study of the flora of Central Asia. In 1859, a Russian scientist Maximovich made a list of plant species of Amur, which included the vascular plant species of Mongolia for the first time [24]. Later, the Science Committee of Mongolia and the Mongolian committee at the Russian Academy of Sciences, founded in the 1920's, organized agricultural expeditions in 1947-1951, which played an important role in the study of plant resources of Mongolia [33].

As a result of this expedition, V.I. Grubov
(1955) compiled the "Conspectus of the flora of Mongolia", where 1877 species of vascular plants belonging to 552 genera and 97 families were included. The number of species in Mongolian flora increased up to 2239 in V.I. Grubov's key to vascular plants in 1982 and to 2823 in I.A. Gubanov's conspectus in 1996 [13-16, 33, 35]. The last conspectus (Urgamal et al. 2014) includes 3127 species and infraspecific taxa, belonging to 683 genera of 112 families, registered in the Flora of Mongolia and includes data on their nomenclature, classification and distribution (Table 1).

Table 1. Development of the number of vascular plant taxa known from Mongolia

\begin{tabular}{|c|c|c|c|}
\hline Sources and references & Family & Genus & $\begin{array}{c}\text { Species and } \\
\text { infraspecific taxa }\end{array}$ \\
\hline Maximowciz (1859) & - & - & 489 \\
\hline Grubov (1955) & 97 & 555 & 1897 \\
\hline Grubov (1982) & 103 & 599 & 2239 \\
\hline Ulziykhutag (1989) & 122 & 625 & 2443 \\
\hline Gubanov (1996) & 128 & 662 & 2823 \\
\hline Oyuntsetseg \& Urgamal (2013) & $112 *$ & 676 & 3014 \\
\hline Urgamal et al. (2013) & $112 *$ & 679 & 3053 \\
\hline Urgamal et al. (2014) & $112 *$ & 683 & 3127 \\
\hline Urgamal (2017, 2018); Urgamal et al. (2018) & $108 * *$ & 684 & 3160 \\
\hline Urgamal \& Oyuntsetseg (2019) & $108 * *$ & 684 & 3163 \\
\hline In this article & $108 * *$ & 684 & 3191 \\
\hline
\end{tabular}


The present article is a continuation of the previous works dedicated to new national, new regional and location records for "Additions to the vascular plant of Mongolia - I (Urgamal et al. 2013), II (Urgamal 2014), III (Urgamal et al. 2016)", and this is a revision of the floristic composition of Mongolia, which was based on "Urgamal et al. 2014, Conspectus of the vascular plants of Mongolia" [34, 35, 37-39].

In addition, this article reports new records of 10 species for the first time, and also 18 species mentioned in the following

\section{MATERIALS AND METHODS}

The former herbariums of the Institute of General and Experimental Biology of the Mongolian Academy of Sciences (UBA) and the National University of Mongolia (UBU) were checked for new findings and the material was partly critically revised (Thiers 2017) reports by researchers (Doronkin et al. 2015; Kechaykin \& Maxim 2015; Erst et al. 2016, 2017; Urgamal et al. 2016, 2018; Kechaykin 2017; Urgamal \& Oyuntsetseg 2017; Alexeeva 2018; Gundegmaa \& Munkh-Erdene 2018; Korolyuk et al. 2018; Troshkina 2018; Urgamal 2018; Baasanmunkh et al. 2019ab; Li-Qing Zhao et al. 2019; Nobis et al. 2019; Seregin 2016, 2019; Darikhand 2017; Urgamal \& yuntsetseg 2019), and has been added to the vascular flora of Mongolia [1-5, 8-12, 17-23, 25-29, 31, 34-42].

[32]. The voucher specimens are deposited in the herbarium of the Institute of General and Experimental Biology of the Mongolian Academy of Sciences (UBA), and the National University of Mongolia (UBU).

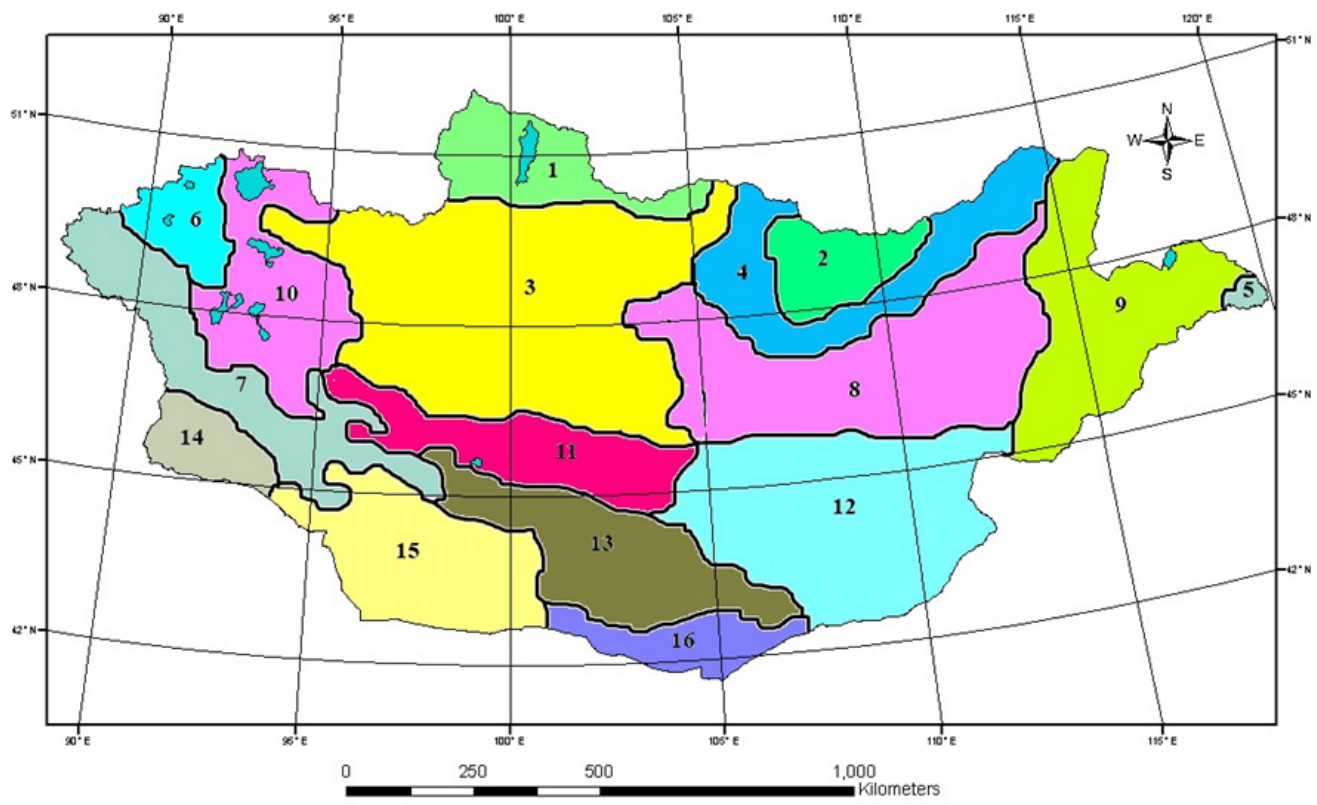

1 - Khuvsgul (Khu), 2 - Khentii (Khe), 3 - Khangai (Kha), 4 - Mongolian Dauria (MD),

5 - Foothills of Great Khingan (FGKh), 6 - Khovd (Kho), 7 - Mongolian Altai (MA), 8 - Middle Khalkh (MKh), 9 - East Mongolia (EM), 10 - Depression of Great Lakes (DGL), 11 - Valley of Lakes (VL), 12 - East Gobi (EG), 13 - Gobi Altai (GA), 14 - Dzungarian Gobi (DG), 15 - Transaltai Gobi (TG), 16 -Alashan Gobi (AG)

Figure 1. Map of phyto-geographical regions of Mongolia (Grubov 1982) 
For species' determination and comparison, we checked herbarium (UBA, UBU), and electronic data of species information and herbarium materials from the following: "Database of the Mongolian Flora" (http:// www.eic.mn/flora/, Urgamal 2014), "Moscow University Herbarium (MW)" (https:// plant.depo.msu.ru; Seregin 2019), “ $A$ virtual approach to the flora of Mongolia (FloraGREIF)" (https://floragreif.unigreifswald.de/floragreif/; Rilke et al. 2013), Tropicos.org. Missouri Botanical Garden. (http://www.tropicos.org), and "Plants of the World Online. Kew Sciences Data Online". (http://plantsoftheworldonline.org/) [12, 26, 27, 29].

The name of the plant families is based on APG IV (2016) system which is also implemented in the Conspectus of the Vascular Plants of Mongolia (Urgamal et al. 2014). Plant names are cited with author names following Brummitt, Powell (1992) and the International Plant Name Index (IPNI; http://www.ipni.org) along with the citation of the reference where the relevant plant name was published $[3,6]$.

We follow the division of Mongolia into 16 phytogeographical regions (Fig.1), which was introduced by Grubov (1982) and phytogeographical regions were defined [13, 14].

All revised localities of materials mentioned in the article are shown on a map (Fig. 2) made using SimpleMappr (http:// www.simplemappr.net).

\section{RESULTS AND DISCUSSION}

A new record of 10 species including Cerastium alpinum, Dianthus repens, Draba alpina, Eritrichium tianschanicum, Gastrolychnis violascens, Iris oxypetala,

Papaver chakassicum, Papaver lapponicum, Potentilla turczaninowiana, Stellaria depressa were reported in this article on Mongolian vascular flora for the first time (Table 2).

Table 2. Information of newly recorded species included in the vascular flora of Mongolia

\begin{tabular}{|l|l|l|}
\hline \multicolumn{1}{|c|}{ Scientific name taxa } & $\begin{array}{l}\text { Region } \\
\text { number }\end{array}$ & \multicolumn{1}{|c|}{ Reported and contributors } \\
\hline $\begin{array}{l}\text { 1. Aquilegia grubovii A. Erst, Luferov, Wang } \\
\text { et Xiang 2016 }\end{array}$ & $2,3,4$ & Erst et al. (2016) \\
\hline 2. Aquilegia xinjiangensis Erst 2017 & 7,14 & Erst et al. (2017); Nobis et al. (2019) \\
\hline 3. Cancrinia krasnoborovii Khanm. 1983 & 10 & Korolyuk et al. (2018) \\
\hline 4. Cerastium alpinum L. 1753 & 6 & In this article \\
\hline 5. Dianthus repens Willd. 1799 & 6,7 & Gundegmaa \& Munkh-Erdene (2018) \\
\hline 6. Draba alpina L. 1753 & 6 & Gundegmaa \& Munkh-Erdene (2018) \\
\hline $\begin{array}{l}\text { 7. Eritrichium tianschanicum Iljin ex Ovc- } \\
\text { zinnikova 2003 }\end{array}$ & 6 & Gundegmaa \& Munkh-Erdene (2018) \\
\hline 8. Gastrolychnis violascens Tolm. 1971 & 7 & Gundegmaa \& Munkh-Erdene (2018) \\
\hline 9. Geranium amurense Tzyren. 2006 & $3,4,9$ & Troshkina (2018) \\
\hline $\begin{array}{l}\text { 10. Geranium saxatile Kar. et Kir. 1842 } \\
\text { 11. Geranium transbaicalicum } \\
\text { subsp. turczaninovii (Serg.) } \\
\text { Peschkova 1996 }\end{array}$ & 7,14 & $\begin{array}{l}\text { Baasanmunkh et al. (2019b); } \\
\text { Nobis et al. (2019) }\end{array}$ \\
\hline 12. Iris biglumis Vahl 1806 & 3,4 & Troshkina (2018) \\
\hline
\end{tabular}




\begin{tabular}{|c|c|c|}
\hline 13. Iris oxypetala Bunge 1832 & 16 & Seregin (2019) \\
\hline 14. Iris schmakovii Alexeeva 2018 & 1 & Alexeeva (2018) \\
\hline 15. Myriophyllum sibiricum Kom. 1914 & 5 & Baasanmunkh et al. (2019a) \\
\hline 16. Papaver chakassicum Peschkova 1994 & 6,7 & Gundegmaa \& Munkh-Erdene (2018) \\
\hline $\begin{array}{l}\text { 17. Papaver lapponicum (Tolm.) Nordh. } \\
1931\end{array}$ & 7 & Gundegmaa \& Munkh-Erdene (2018) \\
\hline $\begin{array}{l}\text { 18. Potentilla ekaterinae Kamelin ex Ke- } \\
\text { chaykin } 2017\end{array}$ & 13 & Kechaykin (2017) \\
\hline 19. Potentilla schmakovii Kechaykin 2015 & 7 & $\begin{array}{l}\text { Kechaykin \& Maxim (2015); Gundegmaa \& } \\
\text { Munkh-Erdene (2018) }\end{array}$ \\
\hline $\begin{array}{l}\text { 20. Potentilla turczaninowiana Stschegl. } \\
1854\end{array}$ & 6,7 & In this article \\
\hline $\begin{array}{l}\text { 21. Potentilla } x \text { vanzhilii V. Gundegmaa et } \\
\text { Kechaykin } 2018\end{array}$ & 3 & $\begin{array}{l}\text { Gundegmaa \& Kechaykin (2018) } \\
\text { Urgamal (2018) }\end{array}$ \\
\hline 22. Ranunculus songaricus Schrenk 1842 & 14 & Nobis et al. (2019) \\
\hline 23. Silene alexandrae B. Keller 1912 & 14 & Baasanmunkh et al. (2019b) \\
\hline 24. Stellaria depressa Em. Schmid 1932 & 7 & Gundegmaa \& Munkh-Erdene (2018) \\
\hline 25. Stipa khovdensis L.Q. Zhao 2019 & 3,6 & Li-Qing Zhao et al. (2019) \\
\hline $\begin{array}{l}\text { 26. Tripleurospermum limosum (Maxim.) } \\
\text { Pobed. } 1961\end{array}$ & 5 & $\begin{array}{l}\text { Wu, Z. Y., Raven, P. H. \& Hong, } \\
\text { D. Y., eds., Flora of China (2011); } \\
\text { Flann, C. (ed). (2009) }\end{array}$ \\
\hline 27. Trollius dschungaricus Regel 1880 & 14 & Darikhand (2017) \\
\hline 28. Typha latifolia L. 1753 & 5 & Baasanmunkh et al. (2019a) \\
\hline
\end{tabular}

The newly added species of the following families and genera include (Table 3): Caryophyllaceae (5 species), Ranunculaceae (4 species), Rosaceae (4 species), families and Potentilla (4 species), Geranium (3 species), and Iris ( 3 species). The most made additions to the following phyto-geographical regions of Mongolia are: Mongolian Altai ( 9 species), Khovd (7 species), and Khangai (6 species) regions (Table 4).

Currently, 3191 taxa (including 134 subspecies and 34 varieties) of vascular plants, representing over 684 genera from 108 families, 39 orders, 12 classes, includes 5 divisions, and 3 superclades (Ferns, Gymnospermae and Angiospermae) and they are all registered in Mongolia, respectively.
Since the last conspectus (Urgamal et al. 2014) was published [38-40], 1 genera, 64 species and subspecies have been newly added to the flora of Mongolia. They include new records for 5 species (Aquilegia grubovii, Potentilla ekaterinae, $P$. schmakovii, $P$. vanzhilii, Stipa khovdensis) as "endemic", and 9 species (Aquilegia xinjiangensis, Geranium transbaicalicum subsp. turczaninovii, Iris biglumis, I. schmakovii, Papaver chakassicum, Potentilla turczaninowiana, Silene alexandrae, Stellaria depressa, Trollius dschungaricus) as "sub-endemic" to Mongolia [1, 2, 5, 9-10, 17$19,22,31,36]$. Therefore, currently, a total of 125 species $(3.91 \%)$ are "endemic", and 532 species $(16.65 \%)$ are "sub-endemic" to the vascular flora of Mongolia. 
Newly recorded species from Mongolia:

1. Cerastium alpinum L. (Caryophyllaceae)

Contributors - Gundegmaa \& Munkh-Erdene (2018)

Taxonomic notes: Currently nine species of Cerastium L. are reported in Mongolia (Urgamal et al. 2014). Cerastium alpinum is a new native species to Mongolia. It occurs in species-rich dwarf-herb communities in the alpine meadows.

General distribution: Europe, Russia (N. European part, W. Siberia), and N. America (Canada and Greenland).

Species examined (new record): MONGOLIA. Khovd region (6), Uvs aimag (province), Khovd soum, Tsast mountain, N4934'17.0, E91¹3'18.0, 3700 m. 17 July 2017, V.Gundegmaa, 17-09 (UBA).

2. Dianthus repens Willd. (Caryophyllaceae) Contributors - Gundegmaa \& Munkh-Erdene (2018)

Taxonomic notes: The genus Dianthus L. includes five species reported in Mongolia (Urgamal et al. 2014). Dianthus repens is a new native species to Mongolia. It occurs in stony slopes and rocks in mountain steppe and mountain tundra (Gundegmaa \& MunkhErdene 2018).

General distribution: China (Inner Mongolia), Korea, Russia (N. European and Northern part, Siberia, and Far East), N. America (Alaska and Yukon Territory).

Species examined (new record): Mongolia. Mongolian Altai region (7): Bayan-Olgii aimag, Deluun soum, Khar Yamaat mountain, N46²7'38.4, E91 54 '14.8, 2462 m. 03 July 2015, V.Gundegmaa, 201507021 (UBA). Bayan-Olgii aimag, Altai soum, Chigertein Lake, N4752'17.7, E90²4’27.7, $2321 \mathrm{~m}$, 05.July.2015， V.Gundegmaa， 2015070589 (UBA).
3. Draba alpina L. (Brassicaceae)

Contributors - Gundegmaa \& Munkh-Erdene (2018)

Taxonomic notes: Currently nine species of Draba L. are reported in Mongolia (Urgamal et al. 2014).

Draba alpina is a new native species to Mongolia. It occurs in snowbeds, in moist tundra and gravelly river banks, and on cliff and rocky slopes in the alpine meadows (Gundegmaa \& Munkh-Erdene 2018).

General distribution: N. Europe, Russia (N. European part, Siberia, and Far East), and N. America (Alaska and Greenland).

Species examined (new record): MONGOLIA. Khovd region (6): Uvs aimag, Khovd soum. Turgen-Kharkhiraa mountains, N49 $35^{\prime} 02.55$, E91 ${ }^{\circ} 12^{\prime} 04.61,3207$ m. 27 June 2014, V.Gundegmaa, 14-28, (UBA).

\section{Eritrichium tianschanicum Iljin ex Ovczinnikova (Boraginaceae)}

Contributors - Gundegmaa \& Munkh-Erdene (2018)

Taxonomic notes: Seven species of Eritrichium Schrad. ex Gaudin are noted in Mongolia (Urgamal et al. 2014). Eritrichium tianschanicum is a new native species to Mongolia. It occurs in snowbeds, in moist tundra and gravelly river banks, and on cliff and rocky slopes in the alpine meadows (Gundegmaa \& Munkh-Erdene 2018).

General distribution: China (Tian Shan), Kyrgyzstan, Tajikistan.

Species examined (new record): MONGOLIA. Khovd region (6): Uvs aimag, Khovd soum. N49 $38^{\prime}$, E91 ${ }^{\circ} 12.8,3200$ m. 27 June 2017, V.Gundegmaa, 14-24 (UBA). 


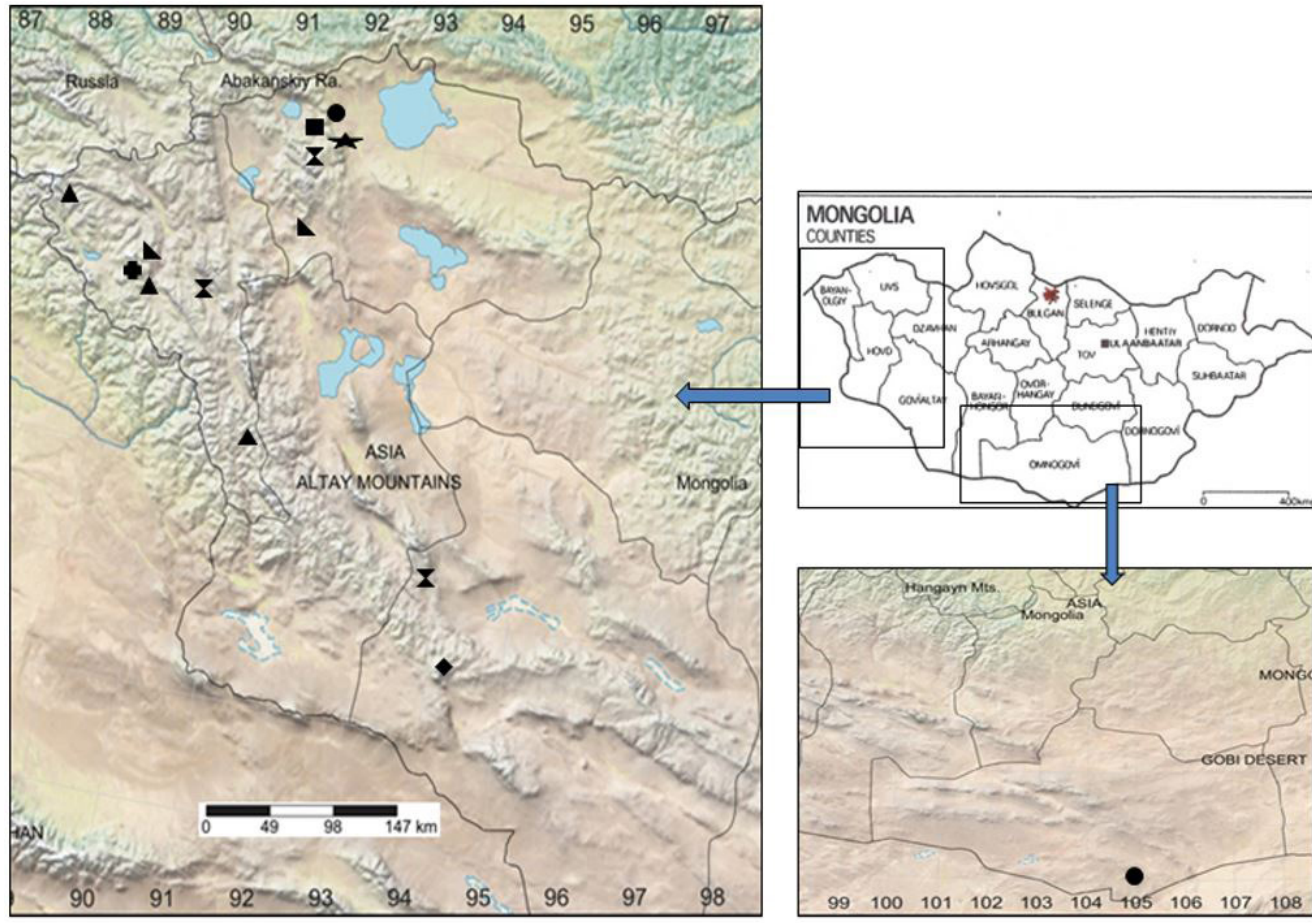

Figure 2. Distribution of newly records species from Mongolia

- Cerastium alpinum
$\Delta$ - Dianthus repens

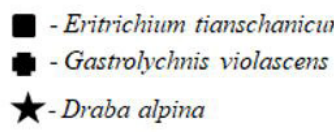

5. Gastrolychnis violascens Tolm. (Caryophyllaceae)

Contributors - Gundegmaa \& Munkh-Erdene (2018)

Taxonomic notes: The genus Gastrolychnis Schrad. ex Gaudin includes one species recognized in Mongolia (Urgamal et al. 2014). Gastrolychnis violascens is a new native species to Mongolia. It occurs in moss-sedge marshes, sedge-mixed grass meadows, along the river banks in the alpine belts (Gundegmaa \& Munkh-Erdene 2018).

General distribution: Russia (Siberia, and Far East).

Species examined (new record): Mongolia. Mongolian Altai region (7): Bayan-Olgii aimag, Altai soum, Chigertein Lake, N4752'17.7, E90²4’27.7, 2320 m. 05 July 2015, V.Gundegmaa, 2015.07.05, 2015070588 (UBA).

\footnotetext{
$\boldsymbol{X}$ - Papaver chakassicum

- Papaver lapponicum

- Iris oxypetala
}

\section{Iris oxypetala Bunge (Iridaceae) Contributors - Seregin (2019)}

Taxonomic notes: The genus Iris L. includes 20-22 species (Urgamal et al. 2014; Doronkin et al. 2015) in Mongolia. Iris oxypetala is a new native species to Mongolia. It occurs in sandy and sandy-pebble desert steppes, debrisstony hill slopes and bottom of sayrs

General distribution: Afghanistan, China, Japan, Kazakhstan, Kyrgyzstan, Korea, Pakistan, Russia, Tajikistan, Uzbekistan.

Species examined (new record): Mongolia. Alashan Gobi region (16): Mongolia, South Gobi aimag, Nomgon soum. $100 \mathrm{~km}$ south of Nomgon soum. Galbiin Gobi. N41038', E105012.8, h=900 m. Coll.: A.I.Gubanov, 1981.07.05, No. 5458, (MW). Det.: A.I.Gubanov, 1981. 


\section{Papaver chakassicum Peschkova}

(Papaveraceae)

Contributors - Gundegmaa \& Munkh-Erdene (2018)

Taxonomic notes: Currently ten species of Papaver L. are reported in Mongolia (Urgamal et al. 2014). Papaver chakassicum is a new native species to Mongolia. It occurs in rocky, pebbled and stony slope in alpine and forest belts (Gundegmaa \& Munkh-Erdene 2018).

General distribution: Russia (Altay, Krasnoyarsk, Tuva). (Sub-endemic).

Species examined (new record): MONGOLIA. Khovd region (6): Uvs aimag, Turgen soum, Turgen mountain, Burgastain river. 01 August 1964, Mongolisch-Deutsche Expedition 1407, 1472 (GAT). Uvs aimag, Ulaangom soum, Kharkhiraa mountain. E91 ${ }^{\circ} 806$, N49$^{\circ} 925,1750$ m. 18 June 1978, H.Ansorge, 44594 (HAL). Uvs aimag, Ulaangom soum, Kharkhiraa mountain. Ovot tal. 10 August 1962, Mongolisch-Deutsche Expedition 1592 (GAT). Mongolian Altai region (7): Bayan-Olgii aimag, Tolbo soum, nearest $4 \mathrm{~km}$ from Tolbo Nuur lake. $2300 \mathrm{~m}$, 26 July 1964, S.Danert, C.Davazamc, P.Hanelt et Sancir,. 3883 (GAT). Gobi-Altai aimag, Tonkhil soum, Sutai Khairkhan mountain, N4437'14.3 E9331'54.8, 3223 m, 9 August 2014, V.Gundegmaa, 14-03 (UBA).

\section{Papaver lapponicum (Tolm.) Nordh. (Papaveraceae)}

Contributors - Gundegmaa \& Munkh-Erdene (2018)
Taxonomic notes: Papaver lapponicum is a new native species to Mongolia. It occurs in dry scree slopes and gravelly ridges in the alpine belt (Gundegmaa \& Munkh-Erdene 2018).

General distribution: N. Europe (Norway, Finland), Russia (European part, Siberia, Far East), N. America (Alaska and Canada).

Species examined (new record): Mongolia. Mongolian Altai region (7): Gobi Altai aimag, Bugat soum, Alag Khairkhan mountain, N453’'416, E940 $07^{\prime} 530,3305$ m, 5 July 2015, V.Gundegmaa, 2015070565 (UBA).

\section{Potentilla turczaninowiana Stschegl.}

\section{(Rosaceae)}

Contributors - Gundegmaa

Taxonomic notes: Potentilla L. includes 73 species in Mongolia (Urgamal et al. 2014). Potentilla turczaninowiana is a new native species to Mongolia. It occurs in stony placers, stony slopes, rocks in alpine.

General distribution: Kazakhstan, Kyrgyzstan, Russia (Altay and Sayan), Tajikistan. (Sub-endemic).

Species examined (new record): MONGOLIA. Khovd region (6): Uvs aimag, Khovd soum, Mountain range of Tsast Bogd Uul mountain, stony fields in mountain tundra, N493'02.55', E91'12'04.61', $3207 \mathrm{~m}$, V.Gundegmaa, 17 July 2017, 1707171 (UBA). Mongolian Altai region (7): Bayan-Olgii aimag, Deluun soum, Chigertein Nuur lake. N4748'31.86', E9007'33.05”, 2725 m, 24 July 2017, V.Gundegmaa, 170724 (UBA).

Table 3. Additions and number of species of following families and genera for the flora of Mongolia

\begin{tabular}{|l|r|l|r|}
\hline Family name & Species number & Genus name & Species number \\
\hline Caryophyllaceae & 5 & Potentilla & 4 \\
\cline { 2 - 3 } Ranunculaceae & 4 & Geranum & 3 \\
\cline { 2 - 4 } Geraceae & 4 & Iris & 2 \\
\cline { 2 - 4 } Iridaceae & 3 & Papaver & 2 \\
Papaveraceae & 3 & Aquilegia & 1 \\
\cline { 2 - 4 } Asteraceae & 2 & Gastrolychnis & 1 \\
\cline { 2 - 4 } & 2 & Cancrinia & \\
\cline { 2 - 4 } & $-48-$ &
\end{tabular}




\begin{tabular}{|c|c|c|c|}
\hline \multirow{2}{*}{$\begin{array}{l}\text { Boraginaceae } \\
\text { Brassicaceae }\end{array}$} & 1 & Draba & 1 \\
\hline & 1 & Eritrichium & 1 \\
\hline \multirow{9}{*}{$\begin{array}{l}\text { Haloragaceae } \\
\text { Poaceae } \\
\text { Typhaceae }\end{array}$} & 1 & Myriophyllum & 1 \\
\hline & 1 & Cerastium & 1 \\
\hline & 1 & Dianthus & 1 \\
\hline & & Ranunculus & 1 \\
\hline & & Silene & 1 \\
\hline & & Stipa & 1 \\
\hline & & Tripleurospermum & 1 \\
\hline & & Trollius & 1 \\
\hline & & $\begin{array}{l}\text { Typha } \\
\text { Stellaria }\end{array}$ & $\begin{array}{l}1 \\
1\end{array}$ \\
\hline 12 families & 28 species & 19 genera & 28 species \\
\hline
\end{tabular}

\section{Stellaria depressa Em. Schmid}

(Caryophyllaceae)

Contributors - Gundegmaa \& Munkh-Erdene (2018)

Taxonomic notes: Stellaria L. includes 21 species in Mongolia (Urgamal et al. 2014). Stellaria depressa is a new native species to Mongolia. It occurs in pebble belts and gravelly soils in high mountain belt (Gundegmaa \&
Munkh-Erdene 2018).

General distribution: China (Tibet, West Himalaya). (Sub-endemic).

Species examined (new record): Mongolia. Mongolian Altai region (7): Bayan-Olgii aimag, Tsengel soum, Tavan Bogd mountain, 3225 m, 24 July 2017, V.Gundegmaa, 24.7.2017, 170724 (UBA).

Table 4. New records for phyto-geographical regions of Mongolia

\begin{tabular}{|l|l|}
\hline \multicolumn{1}{|c|}{ Phyto-geographical region name and numbers } & Numbers of new records \\
\hline 1. Khuvsgul mountain taiga & 2 \\
\hline 2. Khentii mountain taiga & 2 \\
\hline 3. Khangai forest steppe & 6 \\
\hline 4. Mongolian Dauria forest steppe & 4 \\
\hline 5. Foothills of Great Khingan mountain meadow steppe & 3 \\
\hline 6. Khovd mountain semi-desert steppe & 7 \\
\hline 7. Mongolian Altai mountain steppe & 9 \\
\hline 8. Middle Khalkh dry steppe & - \\
\hline 9. East Mongolia steppe & 1 \\
\hline 10. Depression of Great Lakes semi-desert steppe & 1 \\
\hline 11. Valley of Lakes semidesert steppe & - \\
\hline 12. East Gobi semi-desert steppe & - \\
\hline 13. Gobi Altai mountain semi-desert steppe & 1 \\
\hline 14. Dzungarian Gobi desert & 5 \\
\hline 15. Transaltai Gobi desert & - \\
\hline 16. Alashan Gobi desert & 1 \\
\hline & \\
\hline
\end{tabular}



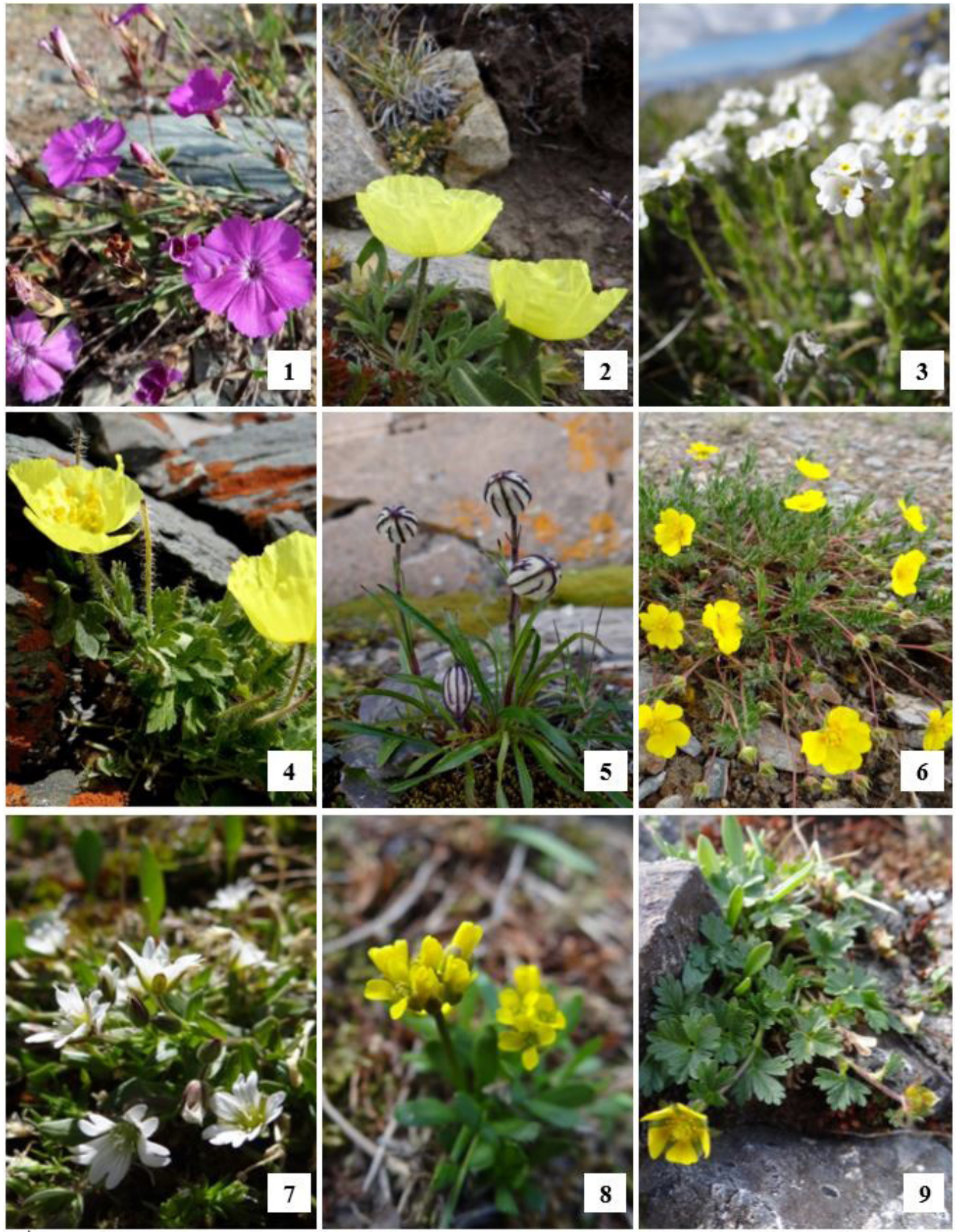

Figure 3. Photograph a newly recorded species for the Mongolian flora (Photos by V.Gundegmaa): 1 -Dianthus repens, 2 - Papaver lapponicum, 3 -Eritrichum tianshianicum, 4 - Papaver chakassicum, 5 - Gastrolychnis violascens, 6 - Potentilla schmakovii,

7 - Cerastium alpinum, 8 - Draba alpina, 9 - Potentilla turczaninowiana 


\section{CONCLUSIONS}

This article contains 28 species of plants newly recorded in Mongolia, and most of them are dominated by the geographical elements of South Siberia, Altai-Sayan Mountain, Central Asia, and Dzungarian Gobi regions.
Acknowledgements. We thank botanists who were supportive of the views expressed in the article. We also thank an anonymous reviewer for constructive comments and suggestions which made the manuscript better.

\section{REFERENCES}

1. Alexeeva, N. B. (2008). Genus Iris L. (Iridaceae) in the Russia. Turczaninowia 11(2): pp. 5-68.

2. Alexeeva, N. B. (2018). New species of Iris L. (Iridaceae) from Mongolia. Turczaninowia, 21(4): pp. 145-149.

3. APG IV. (2016). An update of the Angiosperm Phylogeny Group classification for the orders and families of flowering plants: APG IV. Bot. J. Linn. Soc., 181(1): pp. 1-20.

4. Baasanmunkh Shukherdorj, Takashi Shiga, Oyuntsetseg Batlai, Karsten Wesche, Christiane M. Ritz, Khaliunaa Khurelbaatar, Jae Young Kim, Hyeong Jun Jo, Batkhuu Nyam-Osor, Gyu Young Chung, Hyeok Jae Choi (2019a). Contribution to the knowledge on the flora of Numrug Strictly Protected Area and some parts of East Mongolia. Journal of Asia-Pacific Biodiversity, 12 (1): pp. 14-44.

5. Baasanmunkh, Sh., Oyuntsetseg, B., Lazkov, G.A. Chung, Y., Choi, H. J. (2019b). A new species for Mongolia and new records of vascular plants from Dzungarian Gobi. Turczaninowia, 22(1): pp. 132-136.

6. Darikhand, D. 2017. The study of flora in Northern part of Baitag Bogd Mountain. Ph.D dissetation thesis. Ulaanbaatar, Mongolia (in Mongolian)

7. Brummitt, R.K. \& Powell, C.E. (1992). Authors of Plant Names. Published on the internet. http://www.ipni.org/ [accessed in 2019].

8. Doronkin V., Shaulo D., Han I., Vlasova N., Ivleva V., Enkhtuya L., Munkh-Erdene T., Ochgerel N., and Munkhjargal B. (2015). New records for the flora of Selenge Aimag (Mongolia). Skvortsovia: 2(1): pp. 8-27.

9. Erst, A.S., Luferov, A.N., Kunli Xiang, Wei Wang. (2016). A review of the genus Aquilegia L. (Ranunculaceae) in Mongolia. Systematic notes..., 2016, 114: pp. 37-48.

10. Erst, A.S., Wang, W., Yu, S.X., Xiang, K.L., Wang, J., Shaulo, D.N., Smirnov, S.V., Kushunina, M., Sukhorukov, A.P. \& Nobis, M. (2017). Two new species and four new records of Aquilegia (Ranunculaceae) from China. Phytotaxa, 316 (2): pp. 121-137.

11. Flann, C. (ed). (2009). Global Compositae Checklist. Accessed: 19/02/2019.

12. FloraGREIF - Virtual Flora of Mongolia (http://floragreif.uni-greifswald.de/floragreif/). Computer Centre of University of Greifswald, D-17487 Greifswald, Germany. [accessed 27.03.2019].

13. Grubov, V. I. (1955). Conspectus of the flora MPR. Moskva, Leningrad. (in Russian).

14. Grubov, V. I. (1982). Key to the vascular plants of Mongolia (with an atlas). Leningrad, Nauka: p. 442. (in Russian).

15. Grubov, V. I. (2008). Key to the vascular plants of Mongolia. Ulaanbaatar, Mongolia: Gan Print.

16. Gubanov, I. A. (1996). Conspectus of flora in Outer Mongolia. Moskva, Valang. (in Russian). 
17. Gundegmaa, V. \& Kechaykin, A. A. (2018). A new intersectional hybrid in the genus Potentilla. (Rosaceae) from Northern Mongolia. Turczaninowia, 21(1): pp. 174-179.

18. Gundegmaa, V. \& Munkh-Erdene, T. (2018). Field Guide of Alpine Flowers of the Mongolian Altai Mountains. "Soyombo Printing LLC" Press. Ulaanbaatar, Mongolia.

19. Kechaykin, A. A. (2017). Three new taxa of Potentilla (Rosaceae) from Caucasus and Mongolia. Novitates Systematicae Plantarum Vascularium, Volume 48: pp. 84-88.

20. Kechaykin Alexey, Maxim Kutsev. (2015). Notes on Potentilla L. (Rosaceae) from the Altai. 2. New species from South Siberia and West Mongolia. Feddes Repertorium, 126(3): pp. 73-76.

21. Korolyuk, E. A., Korolyuk, A. Yu., Cheryomushkina, V. A. (2018). Cancrinia krasnoborovii Khanm. - the new species to the flora of Mongolia. Turczaninowia, 21 (4): pp. 40-43.

22. Li-Qing Zhao, Xu Ri, Alatanzhula, Vanjil Gundegmaa, Xian-Guo Qiao and Chimeddorj Mungunchimeg. (2019). Stipa khovdensis (Poaceae), a new species, and a checklist of Stipa s. stricto from Mongolia. Annales Botanici Fennici, 56(1-3): pp. 95-99.

23. Marcin Nobis, Ewelina Klichowska, Ana Terlević, Anna Wrobel, Andrey Erst, Richard Hrivnak, Aleksandr L. Ebel, Valery N. Tikhomirov, Vyacheslav V.Byalt, Polina D. Gudkova, Gergely Kiraly, Laura M. Kipriyanova, Marina Olonova, Renata Piwowarczyk, Artur Pliszko, Stanisław Rosadziński, Alexey P. Seregin, Vitaliy Honcharenko, Jolanta Marciniuk, Paweł Marciniuk, Krzysztof Oklejewicz, Mateusz Wolanin, Oyuntsetseg Batlai, Kateřina Bubikova, Hyeok Jae Choi, Maxim A. Dzhus, Judita Kochjarova, Attila V. Molnar, Agnieszka Nobis, Arkadiusz Nowak, Helena Ot’ahel'ova, Miklós Óvari, Igor I. Shimko, Baasanmunkh Shukherdorj, Gabor Sramkó, Victoria I.Troshkina, Alla V. Verkhozina, Wei Wang, Kunli Xiang \& Elena Yu. Zykova. 2019. Contribution to the flora of Asian and European countries: new national and regional vascular plant records, 8. Botany Letters, 166(2): 163-188.

24. Maximowicz, K. J. (1859). Primitiae florae Amurensis. Mem. Acad. Imp. Sci. St.Petersbourg Divers Savans, 9: pp. 1-467. (in Russian).

25. Oyuntsetseg, B. \& Urgamal, M. (2013). Vascular plants. Convention on Biological diversity the 5th National report of Mongolia.: 21-24. (English and Mongolian).

26. Plants of the World Online. Kew Sciences Data Online. http://plantsoftheworldonline. org/

27. Rilke, S, Najmi, U, Schnittler, M. 2013. Contributions to 'E-Taxonomy' a virtual approach to the flora of Mongolia (FloraGREIF). Feddes Repertorium 123: pp. 219-232.

28. Seregin, A. P. (2016). Making the Russian flora visible: fast digitisation of the Moscow university herbarium (MW) in 2015. Taxon 65 (1): pp. 203-209.

29. Seregin, A. P. (Ed.). (2019). Moscow Digital Herbarium: Electronic Resource. Moscow State University, Moscow. - Available at: https://plant.depo.msu.ru/ [accessed 27.03.2019].

30. Tropicos.org. Missouri Botanical Garden. 09 Apr. $2019<$ http://www.tropicos.org $>$

31. Troshkina, V.I. (2018). New data on the genus Geranium L. (Geraniaceae) in the flora of Mongolia and China. Turczaninowia, 21(4): pp. 181-187.

32. Thiers, B. (2017). Index Herbariorum: A global directory of public herbaria and associated staff. New York Botanical Garden's Virtual Herbarium. http://sweetgum. nybg.org/ih/ [Accessed 10 April 2019

33. Ulziikhutag, N. (1989). Overview of the Flora of Mongolia. State Publishing. (in Mongolian). 
34. Urgamal, M. (2014). Additions to the vascular flora of Mongolia - II. Proceedings of the Institute of Botany, Mongolian Academy of Sciences, 26: pp. 91-97.

35. Urgamal, M. (2017). Change and current overview to the flora of Mongolia (chapter 1.1), The conservation of plant diversity and Red List of Mongolia (chapter 4.2). in volume 3. "Biodiversity of Mongolia" in the book of "Nature Environment of Mongolia" (with 5 volumes). Ministry of Nature Environment. Mongolia. Ulaanbaatar, "Monkhiin useg" Printing. pp.12-70, 257-267.

36. Urgamal, M. (2018). Species Catalogue of Rare and Threatened Vascular Plants of Mongolia. Ulaanbaatar. Mongolia. "Bembi San" Press. P. 193.

37. Urgamal, M., Oyuntsetseg, B. \& Nyambayar, D. (2013). Synopsis and recent additions to the flora of Mongolia. Proceedings of the Institute of Botany, Mongolian Academy of Sciences, 25: pp. 53-72.

38. Urgamal, M., Oyuntsetseg, B., Nyambayar, D. \& Dulamsuren, Ch. (2014). Conspectus of the vascular plants of Mongolia. (Editors: Sanchir, Ch. \& Jamsran, Ts.). Ulaanbaatar, Mongolia. “Admon” Press. P. 334.

39. Urgamal, M., Oyuntsetseg, B., Gundegmaa, V., Munkh-Erdene, T. and Solongo, Kh. (2016). Additions to the vascular flora of Mongolia - III (Since the "Conspectus of the vascular plants of Mongolia 2014"). Proceedings of the Mongolian Academy of Sciences, Vol. 56, 04(220): pp. 32-38.

40. Urgamal, M., Erdenetuya, B., Munkh-Erdene, T., Otgonchuluun, Sh., Zoltsetseg, Ch., Khureltsetseg, L., and Ohseok Kwon. (2018). Medicinal plant diversity in the Southern and eastern Gobi Desert region, Mongolia. Journ. of Ecology and Environment, 2018, pp. 42: (4): 1-13.

41. Urgamal, M. \& Oyuntsetseg, B. (2019). Vascular plants. Biodiversity of Mongolia: a checklist of plants, fungus and microorganisms. Vol.2. /S. Gombobaatar, N. Soninkhishig, D. Batjargal, D. Suran. (eds)/. National University of Mongolia, Mongolian Academy of Sciences, Ministry of Environment and Tourism, and Mongolica Publishing. Ulaanbaatar, Mongolia.

42. Wu, Z. Y., Raven, P. H. \& Hong, D. Y., eds. (2011). Flora of China. volume 20-21 (Asteraceae). Science Press (Beijing) \& Missouri Botanical Garden Press (St. Louis). 